\title{
THE SIGNIFICANCE OF KEY REGULATORS OF APOPTOSIS IN THE DEVELOPMENT AND PROGNOSIS OF PROSTATE CARCINOMA. II. PRODUCTS OF SUPPRESSOR GENES RB AND PTEN, CDKI, FAS
}

\author{
Jana Knillová*, Zdeněk Kolář, Alice Hlobilková
} Laboratory of Molecular Pathology and Institute of Pathology, Faculty of Medicine, Palacký University, 77515 Olomouc,
Czech Republic, e-mail: madarova@tunw.upol.cz

Received: April 20, 2003; Accepted in revised form June 15, 2003

Key words: Prostate cancer / Apoptosis / Gene expression / Rb / PTEN / CDKI / Fas

The molecular basis for the transition of carcinoma of the prostate from androgen-dependent to androgen-independent growth is largely unknown. Currently for example, it is not clear whether the androgen-independent phenotype is a result of selection of a subgroup of genetically distinct prostate tumour cells which are already hormone-resistant or a genetic adaptation of prostate tumour cells to the hormone therapy itself. It has also been established that prostate tumour transformation is a result of homeostatic control defects, a line of thinking directed toward elucidating the apoptotic profile of prostate tumour cells that may be important in determining prognosis, response to therapy and illness progression. Main consideration in this part of rewiev is given to the role of tumour suppressor genes $\mathrm{pRb}$ and PTEN and also the natural inhibitors of cyclin dependent kinases - proteins $\mathrm{p} 21^{\text {War1/Cip1 }}$ and $\mathrm{p} 27^{\mathrm{Kip1}}$. Attention is also given to the role of FAS-mediated pathways in apoptosis induction.

$\mathrm{Rb}$

Retinoblastoma gene $(\mathrm{Rb})$, a member of the tumour suppressor gene family, is localized on the short arm of chromosome 13 . It codes the cell cycle regulating $110 \mathrm{kDa}$ protein and it is expressed in the majority of cell types regardless of their proliferative status. Inactivation of both copies of the gene gives rise to ocular tumours (retinoblastomas) in the same way as other neoplasms ${ }^{1}$. Retinoblastoma protein $(\mathrm{pRb})$ may be phosphorylated in various sites and its phosphorylation status changes during different phases of the cell cycle. Nonphosphorylated or hypophosphorylated forms of the protein block transition through the restriction point of the cell cycle. In this form, $\mathrm{pRb}$ and its related proteins $\mathrm{p} 170$ and p130 ("pocket proteins") bind transcription factors, mainly members of the E2F (E2F1-3) and DP families. These transcription factors are implicated in the regulation of the expression of genes necessary for progression to the $\mathrm{S}$ phase and binding by $\mathrm{pRb}$ blocks their activity. During progression through the G1 phase, pRb is phosphorylated. This facilitates the release and activation of E2F/DP transcription factors and permits progression to late G1 phase and completion of the cell cycle $^{2}$. Key components of the cell cycle initiating $\mathrm{pRb}$ phosphorylation include D cyclins and associated kinases cdk4 and cdk6. Complex cyclin E/cdk2 is then responsible for $\mathrm{pRb}$ hyperphosphorylation. Cells with permanently overphosphorylated $\mathrm{pRb}$, in other words those with overactive or insufficiently inhibited cdk4 (6)/cyclin D, and cells which are unable to dephosphorylate $\mathrm{pRb}$ or lack the ability to express pRb, do not control the restriction point and pass it without stopping. All these defects can lead to uncontrolled growth ${ }^{1,3}$. As far as proliferation is concerned Hofman et al. demonstrated that a biphasic dose-dependent response of the prostatic cancer cell line LNCaP to androgens is closely reflected in $\mathrm{pRb}$ phosphorylation, E2F activity and $\mathrm{p} 27^{\mathrm{Kip} 1}$ protein expression ${ }^{4}$.

Mutational changes in the $\mathrm{Rb}$ gene found in specific tumours are linked to aggressive behaviour and poor clinical prognosis ${ }^{5,6}$. Molecular based studies of $\mathrm{Rb}$ alterations in prostate cancer are limited however and thus no firm conclusion can be drawn. Single stranded conformation polymorphism analysis (SSCP) of RNA showed that $16 \%$ of human primary tumours had altered $\mathrm{Rb}^{7,8}$. Other research groups evaluated genetic alterations in the region of the $\mathrm{Rb}$ gene on the basis of loss of heterozygosity ( $\mathrm{LOH})$. In $27-60 \%$ primary prostate cancer cases LOH has been described. LOH in the $\mathrm{Rb}$ gene has also been found in benign prostatic hyperplasia (BPH) samples ${ }^{8-10}$. Debatable is whether inactivation of the $\mathrm{Rb}$ gene is a primary event in the pathogenesis of prostate cancer or a secondary event connected to the progression of the illness ${ }^{11}$. Bookstein et al. studied $\mathrm{pRb}$ protein expression in three different prostate cancer cell lines and found that the DU-145 cell line contained abnormally small protein translated from $\mathrm{Rb}$ mRNA transcript and lacking 105 nucleotides encoded on exon $21\left(\right.$ ref. $\left.^{12}\right)$. The finding of short mRNA transcript in DU-145 cell line was confirmed in two further studies $^{13,14}$. In prostate cancer tissues however no similar 
alterations have been found to date ${ }^{8}$. Using immunohistochemical techniques, absence of $\mathrm{pRb}$ protein has been described in 17-78\% of cases. The significance of $\mathrm{Rb}$ alterations in prostate cancer, however, remains problematic $^{8,9,14}$. There is insufficient correlation between $\mathrm{LOH}$ in $\mathrm{Rb}$ and missing $\mathrm{pRb}$ expression. In addition, evaluation of $\mathrm{pRb}$ expression may be influenced by fixation artefacts, variability of immunohistochemical reaction (sensitivity and specificity of antibody) and interpretation of staining results. Whether the reduction of $\mathrm{pRb}$ staining has any significance for predicting the malignancy potential of a given carcinoma lesion is a question requiring further study in a well characterised population of prostate cancer patients ${ }^{8}$.

$\mathrm{Rb}$ activity is also connected to apoptosis induction in different cell environments. Day et al. have documented the functional role of $\mathrm{Rb}$ in signalling apoptosis in prostate tumour cell studies ${ }^{15}, 16$. Inactivation of the $\mathrm{Rb}$ apoptotic pathway is important in the case of metastatic progression of prostate tumours ${ }^{6}$. Kaltz-Wittmer et al. carried out a FISH analysis of gene aberration (myc, CCNDI, erbB-2, Rb and AR) in advanced prostate tumours before and after androgen therapy. Loss of the $\mathrm{Rb}$ gene was almost four times more frequent after therapy than before therapy. Changes in the number of gene copies before and after therapy demonstrate the possibility that these genes are connected to exit from androgen control ${ }^{17}$. Despite the fact that the predisposition of prostatic epithelial cells to cancerogenesis in the absence of Rb tumour suppressor gene has been shown in rats, the prognostic evaluation of $\mathrm{Rb}$ is not currently clear $^{18,19}$.

\section{PTEN/MMAC1/TEP1}

Gene PTEN/MMAC1/TEP1 (PTEN) is localised on chromosome 10q23.3 and codes dual-specificity phosphatase. This has the ability to dephosphorylate both tyrosine phosphate and serine/threonine phosphate residues on proteins. The in vivo function of PTEN appears to be dephosphorylation of phosphatidylinositol 3,4,5-triphosphate ${ }^{20-22}$. PTEN possesses a PDZ [postsynaptic density protein (PDS-95)/Drosophila disc large tumour suppressor (dlg)/tight junction protein (ZO1)] motif represented by the amino acids Ile-Thr-Lys-Val. In addition to the site responsible for dual-phosphatase activity, the amino-terminal domain of PTEN protein contains a region which is homologous to cytoskeletal proteins tensin and auxillin ${ }^{23}$. PTEN may be also a component of the signalling complex associated with focal adhesion kinase (FAK) ${ }^{24}$. $\mathrm{LOH}$ in the region $10 \mathrm{q} 23.3$ is linked to a number of tumours including carcinomas of the prostate and mutations of PTEN were, contrary to other tumours, also found in prostate tumour cell lines, xenografts and tissue samples from hormone resistant prostate tumours ${ }^{20,25-27}$. LOH in the PTEN locus was confirmed in 29-42\% tumours of prostate and screening for homozygous deletions of the gene showed a se- cond mutational event in $43 \%$ of prostate tumours. LOH of $10 \mathrm{q}$ was found in $20 \%$ tumours localised in the prostate and in $46 \%$ metastases ${ }^{11,28}$. Suzuki et al. found $55 \% \mathrm{LOH}$ for PTEN in patients who had died of hormone-refractory prostate cancer with widespread metastases $^{29}$. Wang et al. concluded that from $10 \%$ to $15 \%$ of stage $\mathrm{T} 2$ prostate carcinomas had homozygous deletion of the PTEN gene ${ }^{30}$. The aim of Rubin et al. was to find the frequency of LOH at 10q23.3 in the region of PTEN in men with and without lymph node positive prostate cancer. The findings of an elevated number of alterations in node-positive tumours of the prostate suggest that $10 \mathrm{q} 23.3$ is a marker for metastatic progression $^{27}$. Mutations and genetic alterations (LOH) seem to be more frequent in higher stage cancers and prostatic tumour cell lines than in localised prostate tumours. In patients with an inherited predisposition to cancer of the prostate no germ line PTEN mutations were found ${ }^{31,32}$. The majority of deletions involving PTEN eliminate the PDZ motif and thereby interrupt interactions with other proteins possessing PDZ domains ${ }^{33}$. These include Fas (CD95/APO-1) and adenomatous polyposis coli (APC) tumour suppressor protein containing the C-terminal PDZ motif. The majority of identified mutations block phosphatase activity or influence the stability of the enzyme. Hence phosphatase activity of PTEN is thought to be critical for tumour suppressor activity $^{34}$. This suggests that PTEN may be an important tumour suppressor in a subset of prostate carcinomas. Inactivation of PTEN by contrast may be an important secondary genetic event contributing to progression of prostate cancer and giving prostatic tumour cells a selective advantage ${ }^{11}$. McMenamin et al. inquired into PTEN expression in a series of archival paraffin embedded samples of prostate cancer. PTEN expression was seen in secretory cells while a complete absence of PTEN expression correlated with Gleason score and with advanced pathological stage. Loss of PTEN protein thus correlated with the pathological markers of poor prognosis in prostate tumours ${ }^{35}$.

The ability of PTEN to regulate apoptosis is the subject of active research. Davies et al. tested biological and biochemical effects of PTEN expression in LNCaP cell line which is devoid of functional gene products. Expression of PTEN in these cells was found to be related to inhibition of Akt/PKB activation, to apoptosis induction and growth inhibition. Overexpression of Bcl-2 blocked apoptosis induced by PTEN and p53, but not the growth-suppressive effects of PTEN suggesting that the growth-regulatory effects of PTEN involve multiple pathways ${ }^{36}$. Sharrard et al. investigated the influence of PTEN expression on prostate tumour cell lines. They showed that overexpression of PTEN in transfected cell lines led to shrinkage and rounding of cells but did not result in increased levels of classical apoptosis ${ }^{37}$. Huang et al. using prostate cancer cell lines showed that loss of PTEN leads to up-regulation of the bcl-2 gene, thus contributing to survival and chemoresistance of prostate cancer cells ${ }^{38}$. Studies of the mutual antagonism 
between PTEN and androgen receptor (AR) was the subject of Li et al's work. On the one hand, PTEN repressed the transcriptional activity of AR, on the other hand, androgens protected prostate cancer cells from PTEN-induced apoptosis in an AR-dependent manner ${ }^{39}$. Loss of PTEN function may induce tumourigenesis through unopposed activity of AR as well as contribute to the resistance of prostate cancers to androgen ablation therapy. Also the combined tumour-suppressive activity of PTEN and p27 $7^{\mathrm{Kip} 1}$ through the control of the cell cycle progression shows the key significance of these proteins. Their co-operation in prostate cancer has been demonstrated in mouse model by Di Cristofano et al. PTEN activity leads to the induction of p27 ${ }^{\mathrm{Kip} 1}$ expression, which in turn can negatively regulate transition through the cell cycle. Thus, the inactivation of $\mathrm{p} 27^{\mathrm{Kip} 1}$ may be epistatic to PTEN in the cell cycle control ${ }^{40}$.

$\mathrm{p} 21^{\mathrm{Waf} 1 / \mathrm{Cip} 1 / \mathrm{SdII}}$

Protein $\mathrm{p} 21^{\text {Waf1/Cip1/SdII }}$ ( $\mathrm{p} 21$ ) belongs to the KIP/CIP family of CDK inhibitors. Gene encoding for p21 is localised on chromosome $6 \mathrm{p} 21$. It has been shown that p21 inhibits activity of each member of the cyclin/CDK family and thus it is a universal inhibitor of cyclin dependent kinases. In normal cells p 21 creates quaternary complexes together with $\mathrm{CDK}$, cyclin and proliferative cell nuclear antigen (PCNA). It is interesting that according to stoichiometry of the cyclin/CDK/p21 complex it may function as a factor stimulating kinase activity or as an inhibitor ${ }^{41}$. Apart from inhibiting cyclin/CDK complexes, protein p21 also interacts with complex PCNA-DNA polymerase $\delta$. It is, as well, an essential protein for DNA replication and repair ${ }^{42}$. In the case of DNA damage, p21 is a key protein for inducing G1 cell cycle arrest. Its expression is regulated by tumour suppressor gene $\mathrm{p} 53^{43}$. In addition, in human cells p53 as well as p21 appear to be important for maintaining the G2 checkpoint ${ }^{44}$. This aside, p21 may be activated in a p53 independent way, mainly during development ${ }^{45}$. Protein p21 also exerts other cell functions such as differentiation, senescence or apoptosis. However, the role of p21 in apoptosis induction remains controversial $^{46}$.

The role of p21 expression in prostate cancer and its prognostic value is at the present little understood. $\mathrm{Mu}$ tations of p21, in contrast to mutations of p53 and pRb, should be very rare in tumour cells ${ }^{47}$. However, SSCP analysis of primary tumours of the prostate, which lacked demonstrable p53 mutations, revealed that $18 \%$ of the tumours carried p21 mutations ${ }^{48}$. LOH involving chromosome $6 \mathrm{p}$, where $\mathrm{p} 21$ gene is also localised (6p21.2), has been found in prostate cancer. Loss of p21 activity may thus contribute to progression of prostate can$\operatorname{cer}^{11,49}$.

The relation between p21 and cell proliferation, apoptosis, expression of p53 and Bcl-2 is very variable and the clinical significance of p21 immunostaining is still unclear. In prostate cancer cell lines, p21 has an inhibitory influence on cell growth but in clinical studies of prostate cancer the role of p21 is almost untouched $^{50,51}$. Byrne et al. showed via immunohistochemical analysis of p21 protein in a series of 40 tumour samples no correlation between p21 immunoreactivity and tumour progression, grade or stage ${ }^{52}$. Further immunohistochemical analysis of $\mathrm{p} 21$ expression in 213 cases carried out by Aaltomaa et al. however demonstrated that p21 expression is significantly linked to high Gleason score, aneuploidy, high cell number in the $\mathrm{S}$ phase and also to expression of Ki-67, Bcl-2, cyclins A and D. p21 expression in this study significantly correlated with unfavourable prognosis and p21 was thus described as an independent predictor of survival in prostate cancer patients $^{51}$. Other recent studies confirm these findings. Sarkar et al. showed the correlation between p21 expression, pathological stage and Gleason score. They also found differences in values of p21 as a prognostic marker of disease-free survival in Caucasians vs. African Americans and suggested that progression to prostate cancer may have different mechanisms in different ethnic groups ${ }^{53}$. A correlation between $\mathrm{p} 21$ and proliferation has also been described ${ }^{54,55}$. In both studies positivity of p21 was linked to high proliferative index Ki-67. Overexpression of p21 before and after androgen deprivation therapy may characterise a subgroup of advanced carcinomas of the prostate with paradoxically high proliferative index and significantly poorer prognosis. In patients after radical prostatectomy, not treated by neoadjuvant therapy, a 21 positive phenotype occurred in connection with shortened relapse period ${ }^{56}$. According to Cheng et al. however, p21 positivity was a positive predictor of survival ${ }^{57}$.

The relation between $\mathrm{p} 53$ and $\mathrm{p} 21$ expression is also debatable. A relation exists between these proteins for example in cases of breast cancer but not in tumours of the pancreas. Aaltoma et al. however found no correlation in prostate cancer samples ${ }^{51}$. The relation between p21 and p53 expression is complex and seems to be specific for single tumour types. Osman et al. found a significant relation between p21 and MDM2 expression. These authors assume that progression to prostate tumour involves inactivation of $\mathrm{p} 53$ due to overexpression of MDM2 and that transactivation of p21 is caused by an p53 independent signal pathway ${ }^{55}$.

There are also interesting works focused on the relation between androgens, AR and p21 expression. Agus et al. studied factors connected to regression of prostate cancer after androgen deprivation. They found that in early phases after androgen withdrawal AR expression was decreased, followed by transient increase in p53 and $\mathrm{p} 21$ protein expression ${ }^{58}$. In an androgen-independent cell line derived from parental LNCaP cell line it has been shown that the use of antisense oligonucleotides against AR caused reduction of AR levels leading to increase in p21 expression and partial restoration of androgen-dependence ${ }^{59}$. In other work it has been demonstrated that androgens stimulated endogenous p21 
gene expression at the transcription level. The androgen-responsive element (ARE), which mediates the response to androgens and increases transcription of $\mathrm{p} 21$, is located within $2.4 \mathrm{~kb}$ p21 gene promotor. Increase in p21 gene expression by androgens shows that p21 may have an antiapoptotic function in epithelial cells ${ }^{60}$. Modulation of p21 expression by androgens has been also confirmed immunohistochemically ${ }^{61}$.

\section{$\mathrm{p} 27^{\mathrm{Kip} 1}$}

Protein $\mathrm{p} 27^{\mathrm{Kip} 1}$ (p27) belongs to the CIP/KIP family of CDK inhibitors. Gene coding for p27 is localised on chromosome 12p13 (ref. ${ }^{62}$ ). Expression of p27 is regulated by contact inhibition and specific growth factors (for example TGF-beta, IL-2, cAMP). p27 expression levels are higher in quiescent and differentiating cells. Protein p27 accumulates in the G1 phase of the cell cycle and causes its arrest. When the cell enters the cell cycle following mitogenic stimulation, p27 is proteolytically degraded and the p27 mediated repression of complexes cyclin E/cdk2 is released. Apart from its presumed role as a tumour supressor, many other functions are attributed to $\mathrm{p} 27 \mathrm{such}$ as regulation of drug resistence in solid tumours, as an auxiliary factor in apoptosis, etc. $^{63}$

Elucidating the role of p27 as CDK inhibitor in normal and neoplastic cells has to date been the focus of major attention. It has been shown that loss of p27 protein expression may lead to tumour development and progression. Absence of p27 in tumours is connected to poor prognosis although surprisingly few p27 mutations have been described in tumours ${ }^{47}$. Lowered levels of p27 in tumours are caused chiefly at posttranscriptional levels owing to a higher degradation by the ubiquitin/proteasome pathway. Another important mechanism for p27 degradation seems to be phosphorylation. Among further mechanisms connected to regulation of p27 expression are methylation and regulation on the protein synthesis level (mRNA stability, localisation and translation $)^{64}$.

The actual diagnostic and prognostic significance of p27 expression in different tumours has been investigated more recently. Virtually all studies have shown low expression of p27 in more aggressive tumours and a number have confirmed the usefulness of p27 as an independent prognostic and/or diagnostic marker in a wide spectrum of human tumours including carcinoma of breast, tumour of large intestine, adenocarcinoma of prostate, esophagal adenocarcinoma, nonsmall cell lung cancer, malignant melanoma and endocrine tumours $^{63,65}$. Mutational inactivation of p27 in tumours of the prostate is infrequent ${ }^{47}$. Methylation $\mathrm{CpG}$ islets has also been described. However it is not frequent and does not seem to be the mechanism responsible for deregulation of p27 (ref. ${ }^{66}$ ). No further mutations have been identified $^{67}$.
A series of studies analysed p27 expression in prostatic adenocarcinomas. Guo et al. for example first showed the correlation between loss of protein expression, higher grade of tumour and proliferative status ${ }^{68}$. Their results were confirmed in further studies. In addition p27 expression indirectly correlated with higher Gleason score, with occurrence of metastasis to lymphatic glands, and anueploidy ${ }^{69,70}$. It has also been shown that low p27 expression is an independent predictor of treatment failure and an independent prognostic factor for relapsing illness or shorter survival time ${ }^{63,71,72}$. Thomas et al. used p27 to preselect patients with high risk of relapse. In their group of patients p27 expression in preoperative samples significantly correlated with p27 expression in samples after radical prostatectomy ${ }^{73}$. p27 expression in benign lesions is not clear. Cordon-Cardo et al. found almost undetectable levels of protein p27 and p27 mRNA in BPH in epithelial cells and the stromal cells of BPH lesions. This finding would support the concept that $\mathrm{BPH}$ is not a precursor to prostate can$\operatorname{cer}^{74}$. By contrast, other work using immunohistochemical determination of p27 in normal and in benign prostatic epithelium, as well as studies of the possible existence of abnormalities in the progression of prostatic carcinomas, found that $\mathrm{p} 27$ expression is expressed constitutively in normal and benign prostate tissue ${ }^{75}$. Its expression is apparently lowered following neoplastic progression from preinvasive lesions to invasive carcinomas and metastasis. There is, in addition, an interesting study showing that cell cycle regulators are potential epigenic targets for the prevention of prostate cancer through suitable dietary supplements such as silymarin, genisten, and $\mathrm{EGCG}^{76}$.

\section{Fas (Apo-1/CD95)}

Fas (Apo-1/CD95) is a death receptor belonging to the tumour necrosis factor receptor (TNFR) family. It is a cell-surface receptor protein which may initiate certain intracellular signalling pathways leading to apoptosis ${ }^{77,78}$. It may be activated by its natural ligands (FasL/CD95L) or nonspecifically by antibodies against its internal domain. Fas and FasL play an important role in these types of physiological apoptosis where they exert control chiefly in the immune system. They may also contribute to cancer cell's escape from immune system control. Mutations of the genes coding for Fas or FasL may lead to lymphoproliferative and autoimmune diseases $^{79}$. FasL is a homotrimeric molecule and each FasL binds three molecules of Fas. Trimerisation of Fas results in the recruitment of the cell death inducing signalling complex (DISC) which includes the adaptor protein FADD and procaspase $8\left(\right.$ ref. $\left.^{78}\right)$. Activation of caspase 8 in turn leads to activation of the execution phase of the apoptotic programme. This appears to follow one of two pathways: (1) via direct cleavage and activation of caspase 3 or (2) by indirectly causing the 
release of mitochondrial cytochrome c. This creates apoptosom with APAF-1 and procaspase $9\left(\right.$ ref. $\left.^{80}\right)$.

The importance of the Fas signalling cascade in prostate cells was shown in apoptosis induced by castration in normal rat prostate ${ }^{81}$. Fas is expressed in several prostatic carcinoma cell lines but its in vivo expression in normal prostate and in prostate cancer is poorly understood. Diaz et al. showed Fas expression in secretory cells in benign samples of prostatic tissue, expression in all locally growing tumours and significantly decreased expression in prostate carcinomas compared with benign prostate. The decrease was inversely related to the malignant grade of the tumours. Diminished expression of Fas according to this study seems to be an early molecular event in prostate cancer ${ }^{82}$. Mutations of the Fas gene might be involved in proliferative diseases of the prostate by prolongation of programmed cell death of prostatic epithelial cells. Takayama et al. detected Fas mutations exclusively in high-grade prostatic intraepithelial neoplasia (HGPIN) $(14.3 \%)$ and LOH occasionally found in HGPIN and prostate cancer. These results also show that genetic instability may occur during the early phase of prostate carcinogenesis ${ }^{83}$. The evidence from several studies shows that activation of the Fas/FasL pathway is connected with sensitisation of androgen-independent human prostatic cells during apoptotic response to different chemotherapeutic compounds $^{84,85}$. The pathways leading to Fas mediated apoptosis in prostate cancer cell lines are intact as suggested from apoptotic program which may be triggered either by Fas-ligation in the Fas-sensitive cell lines PC3 and ALVA31 or by rendering the Fas-resistant cell lines DU145 and JCA1 by Fas combined treatment with antiFas monoclonal antibody and cycloheximide ${ }^{86}$. Further works have shown that the mitochondrial pathway is implicated in Fas-mediated apoptosis in prostate cancer cell lines ${ }^{87}$. Two of the early events after Fas ligation are the release of cytochrome $\mathrm{c}$ from the mitochondria and activation of caspase 9. Processed is also protein Bid and this might activate the mitochondria-dependent apoptotic cascade. Induction of Fas-mediated apoptotis in prostate cancer cell lines using different external Fas agonists i.e., anti-Fas antibodies and membrane-bound FasL, does not seem to be very successful. Adenovirusmediated intracellular expression of FasL seems to be more potent and thus potentially exploitable for gene therapy of prostate cancer ${ }^{88,89}$. If prostatic epithelial cells harbour intact a Fas signalling pathway, sensitisation of androgen-independent tumours to Fas-induced apoptosis becomes an appealing therapeutic target, with potential clinical application in treating advanced prostate cancer ${ }^{6}$.

\section{CONCLUSION}

Tumour progression can be ascribed to an imbalance between proliferation and programmed cell death, which is caused by alterations in the genes essential for regulation of cell growth, differentiation and apoptosis. Re- fractoriness of many types of cancer to available anticancer therapy is very often connected with the selection or acquisition of molecular mechanisms suppressing cell death induction. These mechanisms frequently involve an aberrant expression or function of cell death effectors and growth inhibitors, such as Fas, p21 Waf1/Cip1, $\mathrm{p} 27^{\mathrm{Kip} 1}$ or Rb and PTEN tumour suppressor genes. Recently, analysis of these gene products has yielded important prognostic information for many tumour types. Although a great deal of knowledge about the role of the tumour suppressors and CDK inhibitors in the cell cycle progression and tumour development has accumulated, there are still many unanswered questions. Loss of the function of these genes, potentially involving several different mechanisms, appears to play a role in prostate cancer tumourigenesis, particularly in cancer progression. These recent insights into the molecular basis of cancer and advances in our understanding of the integrated functions governing cell proliferation and apoptosis can permit development of novel therapeutic modalities and new strategies involving the restoration of cell death signalling pathways.

\section{AKNOWLEDGEMENTS}

This work was partly supported by IGA MH CR NC/ 6200-3 and NC/6779-3, and MSM 151100001. Our thanks go to Alexander Oulton for his kind help with translation.

\section{REFERENCES}

1. Goodrich DW, Wang NP, Qian YW, Lee EY, Lee WH. (1991) The retinoblastoma gene product regulates progression through the G1 phase of the cell cycle. Cell 67, 293-302.

2. Rao RN. (1996) Targets for cancer therapy in the cell cycle pathway. Curr Opin Oncol 8, 516-24.

3. Veselý J, Chmela Z, Kryštof V, Hanuš J, Hajdúch M, Strnad M, Havlíček L. (1998) Regulace buněčného cyklu cyklin-dependentními kinázami. Zprav klin farmakol farmac 12, 6-10.

4. Hofman K, Swinnen JV, Verhoeven G, Heyns W. (2001) E2F activity is biphasically regulated by androgens in LNCaP cells. Biochem Biophys Res Commun 283, 97-101.

5. Cordon-Cardo C. Mutations of cell cycle regulators. Biological and clinical implications for human neoplasia. Am J Pathol 1995: 147, 545-60.

6. Bruckheimer EM, Kyprianou N. (2000) Apoptosis in prostate carcinogenesis. A growth regulator and a therapeutic target. Cell Tissue Res 301, 153-62.

7. Kubota Y, Fujinami K, Uemura H, Dobashi Y, Miyamoto H, Iwasaki Y, Kitamura H, Shuin T. (1995) Retinoblastoma gene mutations in primary human prostate cancer. Prostate 27, 314-20.

8. Ruijter E, Montironi R, van de Kaa C, Schalken J. (2001) Molecular changes associated with prostate cancer development. Anal Quant Cytol Histol 23, 67-88.

9. Phillips SM, Barton CM, Lee SJ, Morton DG, Wallace DM, Lemoine NR, Neoptolemos JP. (1994) Loss of the retinoblastoma susceptibility gene (RB1) is a frequent and early event in prostatic tumorigenesis. Br J Cancer 70, 1252-7.

10. Brooks JD, Bova GS, Isaacs WB. (1995) Allelic loss of the retinoblastoma gene in primary human prostatic adenocarcinomas. Prostate $26,35-9$.

11. Bruckheimer EM, Gjertsen BT, McDonnell TJ. (1999) Implications of cell death regulation in the pathogenesis and treatment of prostate cancer. Semin Oncol 26, 382-98. 
12. Bookstein R, Shew JY, Chen PL, Scully P, Lee WH. (1990) Suppression of tumorigenicity of human prostate carcinoma cells by replacing a mutated RB gene. Science 247, 712-5.

13. Sarkar FH, Sakr W, Li YW, Macoska J, Ball DE, Crissman JD. (1992) Analysis of retinoblastoma (RB) gene deletion in human prostatic carcinomas. Prostate 21, 145-52.

14. Tricoli JV, Gumerlock PH, Yao JL, Chi SG, D'Souza SA, Nestok BR, deVere White RW. (1996) Alterations of the retinoblastoma gene in human prostate adenocarcinoma. Genes Chromosomes Cancer 15, 108-14.

15. Day ML, Foster RG, Day KC, Zhao X, Humphrey P, Swanson P, Postigo AA, Zhang SH, Dean DC. (1997) Cell anchorage regulates apoptosis through the retinoblastoma tumor suppressor/ E2F pathway. J Biol Chem 272, 8125-8.

16. Day ML, Zhao X, Vallorosi CJ, Putzi M, Powell CT, Lin C, Day KC. (1999) E-cadherin mediates aggregation-dependent survival of prostate and mammary epithelial cells through the retinoblastoma cell cycle control pathway. J Biol Chem 274, 9656-64.

17. Kaltz-Wittmer C, Klenk U, Glaessgen A, Aust DE, Diebold J, Lohrs U, Baretton GB. (2000) FISH analysis of gene aberrations (MYC, CCND1, ERBB2, RB, and AR) in advanced prostatic carcinomas before and after androgen deprivation therapy. Lab Invest 80, 1455-64.

18. Dunsmuir WD, Gillett CE, Meyer LC, Young MP, Corbishley C, Eeles RA, Kirby RS. (2000) Molecular markers for predicting prostate cancer stage and survival. BJU Int 86, 869-78.

19. Wang Y, Hayward SW, Donjacour AA, Young P, Jacks T, Sage J, Dahiya R, Cardiff RD, Day ML, Cunha GR. (2000) Sex hormone-induced carcinogenesis in Rb-deficient prostate tissue. Cancer Res 60, 6008-17.

20. Li J, Yen C, Liaw D, Podsypanina K, Bose S, Wang SI, Puc J, Miliaresis C, Rodgers L, McCombie R, Bigner SH, Giovanella BC, Ittmann M, Tycko B, Hibshoosh H, Wigler MH, Parsons R. (1997) PTEN, a putative protein tyrosine phosphatase gene mutated in human brain, breast, and prostate cancer Science 275, 1943-7.

21. Steck PA, Pershouse MA, Jasser SA, Yung WK, Lin H, Ligon AH, Langford LA, Baumgard ML, Hattier T, Davis T, Frye C, Hu R, Swedlund B, Teng DH, Tavtigian SV. (1997) Identification of a candidate tumour suppressor gene, MMAC1, at chromosome $10 \mathrm{q} 23.3$ that is mutated in multiple advanced cancers. Nat Genet $15,356-62$.

22. Ali IU, Schriml LM, Dean M. (1999) Mutational spectra of PTEN/ MMAC1 gene: a tumor suppressor with lipid phosphatase activity. J Natl Cancer Inst 91, 1922-32.

23. Lee JO, Yang H, Georgescu MM, Di Cristofano A, Maehama T, Shi Y, Dixon JE, Pandolfi P, Pavletich NP. (1999) Crystal structure of the PTEN tumor suppressor: implications for its phosphoinositide phosphatase activity and membrane association. Cell 99, 323-34.

24. Tamura M, Gu J, Matsumoto K, Aota S, Parsons R, Yamada KM. (1998) Inhibition of cell migration, spreading, and focal adhesion by tumor suppressor PTEN. Science 280, 1614-7.

25. Ittmann M. (1996) Allelic loss on chromosome 10 in prostate adenocarcinoma. Cancer Res 56, 2143-7.

26. Vlietstra RJ, van Alewijk DC, Hermans KG, van Steenbrugge GJ, Trapman J. (1998) Frequent inactivation of PTEN in prostate cancer cell lines and xenografts. Cancer Res 58, 2720-3.

27. Cairns P, Okami K, Halachmi S, Halachmi N, Esteller M, Herman JG, Jen J, Isaacs WB, Bova GS, Sidransky D. (1997) Frequent inactivation of PTEN/MMAC1 in primary prostate cancer. Cancer Res 57, 4997-5000.

28. Rubin MA, Gerstein A, Reid K, Bostwick DG, Cheng L, Parsons R, Papadopoulos N. (2000) 10q23. 3 loss of heterozygosity is higher in lymph node-positive (pT2-3, N+) versus lymph nodenegative (pT2-3, N0) prostate cancer. Hum Pathol 31, 504-8.

29. Suzuki H, Freije D, Nusskern DR, Okami K, Cairns P, Sidransky D, Isaacs WB, Bova GS. (1998) Interfocal heterogeneity of PTEN/ MMAC1 gene alterations in multiple metastatic prostate cancer tissues. Cancer Res 58, 204-9.

30. Wang SI, Parsons R, Ittmann M. (1998) Homozygous deletion of the PTEN tumor suppressor gene in a subset of prostate adenocarcinomas. Clin Cancer Res 4, 811-5.
31. Forrest MS, Edwards SM, Hamoudi RA, Dearnaley DP, Arden-Jones A, Dowe A, Murkin A, Kelly J, Teare MD, Easton DF, Knowles MA, Bishop DT, Eeles RA. (2000) No evidence of germline PTEN mutations in familial prostate cancer. J Med Genet 37, 210-2.

32. Cooney KA, Tsou HC, Petty EM, Miesfeldt S, Ping XL, Gruener AC, Peacocke M. (1999) Absence of PTEN germ-line mutations in men with a potential inherited predisposition to prostate cancer. Clin Cancer Res 5, 1387-91.

33. Teng DH, Hu R, Lin H, Davis T, Iliev D, Frye C, Swedlund B, Hansen KL, Vinson VL, Gumpper KL, Ellis L, El-Naggar A, Frazier M, Jasser S, Langford LA, Lee J, Mills GB, Pershouse MA, Pollack RE, Tornos C, Troncoso P, Yung WK, Fujii G, Bermon A, Steck PA. (1997) MMAC1/PTEN mutations in primary tumor specimens and tumor cell lines. Cancer Res 57, 5221-5.

34. Carter BS, Ewing CM, Ward WS, Treiger BF, Aalders TW, Schalken JA, Epstein JI, Isaacs WB. (1990) Allelic loss of chromosomes 16q and $10 \mathrm{q}$ in human prostate cancer. Proc Natl Acad Sci USA 87, $8751-5$.

35. McMenamin ME, Soung P, Perera S, Kaplan I, Loda M, Sellers WR. (1999) Loss of PTEN expression in paraffin-embedded primary prostate cancer correlates with high Gleason score and advanced stage. Cancer Res 59, 4291-6.

36. Davies MA, Koul D, Dhesi H, Berman R, McDonnell TJ, McConkey D, Yung WK, Steck PA. (1999) Regulation of Akt/PKB activity, cellular growth, and apoptosis in prostate carcinoma cells by MMAC/PTEN. Cancer Res 59, 2551-6.

37. Sharrard RM, Maitland NJ. (2000) Phenotypic effects of overexpression of the MMAC1 gene in prostate epithelial cells. $\mathrm{Br}$ J Cancer 83, 1102-9.

38. Huang H, Cheville JC, Pan Y, Roche PC, Schmidt LJ, Tindall DJ. (2001) Pten induces chemosensitivity in pten-mutated prostate cancer cells by suppression of bcl-2 expression. J Biol Chem 276, 38830-6.

39. Li P, Nicosia SV, Bai W. (2001) Antagonism between PTEN/ MMAC1/TEP-1 and androgen receptor in growth and apoptosis of prostatic cancer cells. J Biol Chem 276, 20444-50.

40. Di Cristofano A, De Acetis M, Koff A, Cordon-Cardo C, Pandolfi PP. (2001) Pten and p27KIP1 cooperate in prostate cancer tumor suppression in the mouse. Nat Genet 27, 222-4.

41. Xiong Y, Hannon GJ, Zhang H, Casso D, Kobayashi R, Beach D. (1993) p21 is a universal inhibitor of cyclin kinases. Nature 366, 701-4.

42. Waga S, Hannon GJ, Beach D, Stillman B. (1994) The p21 inhibitor of cyclin-dependent kinases controls DNA replication by interaction with PCNA. Nature 369, 574-8.

43. el-Deiry WS, Tokino T, Velculescu VE, Levy DB, Parsons R, Trent JM, Lin D, Mercer WE, Kinzler KW, Vogelstein B. (1993) WAF1, a potential mediator of p53 tumor suppression. Cell 75, 817-25.

44. Bunz F, Dutriaux A, Lengauer C, Waldman T, Zhou S, Brown JP, Sedivy JM, Kinzler KW, Vogelstein B. (1998) Requirement for p53 and p21 to sustain G2 arrest after DNA damage. Science 282, 1497-501.

45. Michieli P, Chedid M, Lin D, Pierce JH, Mercer WE, Givol D. (1994) Induction of WAF1/CIP1 by a p53-independent pathway. Cancer Res 54, 3391-5.

46. Bissonnette N, Hunting DJ. (1998) p21-induced cycle arrest in G1 protects cells from apoptosis induced by UV-irradiation or RNA polymerase II blockage. Oncogene 16, 3461-9.

47. Sherr CJ. (1996) Cancer cell cycles. Science 274, 1672-7.

48. Facher EA, Becich MJ, Deka A, Law JC. (1997) Association between human cancer and two polymorphisms occurring together in the p21Waf1/Cip1 cyclin-dependent kinase inhibitor gene. Cancer 79, 2424-9.

49. Gao X, Chen YQ, Wu N, Grignon DJ, Sakr W, Porter AT, Honn KV. (1995) Somatic mutations of the WAF1/CIP1 gene in primary prostate cancer. Oncogene 11, 1395-8.

50. Gotoh A, Kao C, Ko SC, Hamada K, Liu TJ, Chung LW. (1997) Cytotoxic effects of recombinant adenovirus p53 and cell cycle regulator genes (p21 WAF1/CIP1 and p16CDKN4) in human prostate cancers. J Urol 158, 636-41.

51. Aaltomaa S, Lipponen P, Eskelinen M, Ala-Opas M, Kosma VM. (1999) Prognostic value and expression of p21(waf1/cip1) protein in prostate cancer. Prostate 39, 8-15. 
52. Byrne RL, Horne CH, Robinson MC, Autzen P, Apakama I, Bishop RI, Neal DE, Hamdy FC. (1997) The expression of waf-1, p53 and bcl-2 in prostatic adenocarcinoma. Br J Urol 79, 190-5.

53. Sarkar FH, Li Y, Sakr WA, Grignon DJ, Madan SS, Wood DP Jr., Adsay V. (1999) Relationship of p21(WAF1) expression with disease-free survival and biochemical recurrence in prostate adenocarcinomas (PCa). Prostate 40, 256-60.

54. Baretton GB, Klenk U, Diebold J, Schmeller N, Lohrs U. (1999) Proliferation- and apoptosis-associated factors in advanced prostatic carcinomas before and after androgen deprivation therapy: prognostic significance of $\mathrm{p} 21 / \mathrm{WAF} 1 / \mathrm{CIP} 1$ expression. Br J Cancer $80,546-55$

55. Osman I, Drobnjak M, Fazzari M, Ferrara J, Scher HI, CordonCardo C. (1999) Inactivation of the p53 pathway in prostate cancer: impact on tumor progression. Clin Cancer Res 5, 2082-8.

56. Lacombe L, Maillette A, Meyer F, Veilleux C, Moore L, Fradet Y. (2001) Expression of p21 predicts PSA failure in locally advanced prostate cancer treated by prostatectomy. Int J Cancer 95, 135-9.

57. Cheng L, Lloyd RV, Weaver AL, Pisansky TM, Cheville JC, Ramnani DM, Leibovich BC, Blute ML, Zincke H, Bostwick DG. (2000) The cell cycle inhibitors p21WAF1 and p27KIP1 are associated with survival in patients treated by salvage prostatectomy after radiation therapy. Clin Cancer Res 6, 1896-9.

58. Agus DB, Cordon-Cardo C, Fox W, Drobnjak M, Koff A, Golde DW, Scher HI. (1999) Prostate cancer cell cycle regulators: response to androgen withdrawal and development of androgen independence. J Natl Cancer Inst 91, 1869-76.

59. Wang LG, Ossowski L, Ferrari AC. (2001) Overexpressed androgen receptor linked to $\mathrm{p} 21 \mathrm{WAF} 1$ silencing may be responsible for androgen independence and resistance to apoptosis of a prostate cancer cell line. Cancer Res 61, 7544-51.

60. Lu S, Tsai SY, Tsai MJ. (1999) Molecular mechanisms of androgen-independent growth of human prostate cancer LNCaP-AI cells. Endocrinology 140, 5054-9.

61. Kolář Z, Murray PG, Scott K, Harrison A, Vojtěšek B, Dušek J. (2000) Relation of Bcl-2 expression to androgen receptor, p21WAF1/CIP1, and cyclin D1 status in prostate cancer. Mol Pathol 53, 15-8.

62. Polyak K, Lee MH, Erdjument-Bromage H, Koff A, Roberts JM, Tempst P, Massague J. (1994) Cloning of p27Kip1, a cyclin-dependent kinase inhibitor and a potential mediator of extracellular antimitogenic signals. Cell 78, 59-66.

63. Lloyd RV, Erickson LA, Jin L, Kulig E, Qian X, Cheville JC, Scheithauer BW. (1999) p27kip1: a multifunctional cyclin-dependent kinase inhibitor with prognostic significance in human cancers. Am J Pathol 154, 313-23.

64. Alessandrini A, Chiaur DS, Pagano M. (1997) Regulation of the cyclin-dependent kinase inhibitor p27 by degradation and phosphorylation. Leukemia 11, 342-5.

65. Millard SS, Koff A. (1998) Cyclin-dependent kinase inhibitors in restriction point control, genomic stability, and tumorigenesis. J Cell Biochem Suppl 30-31, 37-42.

66. Kibel AS, Christopher M, Faith DA, Bova GS, Goodfellow PJ, Isaacs WB. (2001) Methylation and mutational analysis of p27(kip1) in prostate carcinoma. Prostate 48, 248-53.

67. Kibel AS, Faith DA, Bova GS, Isaacs WB. (2000) Loss of heterozygosity at $12 \mathrm{P} 12-13$ in primary and metastatic prostate adenocarcinoma. J Urol 164, 192-6.

68. Guo Y, Sklar GN, Borkowski A, Kyprianou N. (1997) Loss of the cyclin-dependent kinase inhibitor p27(Kip1) protein in human prostate cancer correlates with tumor grade. Clin Cancer Res 3, 2269-74.

69. Cheville JC, Lloyd RV, Sebo TJ, Cheng L, Erickson L, Bostwick DG, Lohse CM, Wollan P. (1998) Expression of p27kip1 in prostatic adenocarcinoma. Mod Pathol 11, 324-8.

70. Vis AN, Noordzij MA, Fitoz K, Wildhagen MF, Schroder FH, van der Kwast TH. (2000) Prognostic value of cell cycle proteins p27 (kip1) and MIB-1, and the cell adhesion protein CD44s in surgically treated patients with prostate cancer. J Urol 164, 2156-61.
71. Tsihlias J, Kapusta LR, DeBoer G, Morava-Protzner I, Zbieranowski I, Bhattacharya N, Catzavelos GC, Klotz LH, Slingerland JM. (1998) Loss of cyclin-dependent kinase inhibitor p27Kip1 is a novel prognostic factor in localized human prostate adenocarcinoma. Cancer Res 58, 542-8.

72. Yang RM, Naitoh J, Murphy M, Wang HJ, Phillipson J, deKernion JB, Loda M, Reiter RE. (1998) Low p27 expression predicts poor disease-free survival in patients with prostate cancer. J Urol 159, 941-5.

73. Thomas GV, Schrage MI, Rosenfelt L, Kim JH, Salur G, deKernion JB, Dorey F, Said J, Reiter RE. (2000) Preoperative prostate needle biopsy p27 correlates with subsequent radical prostatectomy p27, Gleason grade and pathological stage. J Urol 164, 1987-91.

74. Cordon-Cardo C, Koff A, Drobnjak M, Capodieci P, Osman I, Millard SS, Gaudin PB, Fazzari M, Zhang ZF, Massague J, Scher HI. (1998) Distinct altered patterns of p27KIP1 gene expression in benign prostatic hyperplasia and prostatic carcinoma. J Natl Cancer Inst 90, 1284-91.

75. Fernandez PL, Arce Y, Farre X, Martinez A, Nadal A, Rey MJ, Peiro N, Campo E, Cardesa A. (1999) Expression of p27/Kip1 is down-regulated in human prostate carcinoma progression. J Pathol 187, 563-6.

76. Agarwal R. (2000) Cell signaling and regulators of cell cycle as molecular targets for prostate cancer prevention by dietary agents. Biochem Pharmacol 60, 1051-9.

77. Ashkenazi A, Dixit VM. (1998) Death receptors: signaling and modulation. Science 281, 1305-8.

78. Pinkoski MJ, Green DR. (1999) Fas ligand, death gene. Cell Death Differ 6, 1174-81.

79. Waring P, Mullbacher A. (1999) Cell death induced by the Fas/Fas ligand pathway and its role in pathology. Immunol Cell Biol 77, 312-7.

80. Schmitz I, Walczak H, Krammer PH, Peter ME. (1999) Differences between CD95 type I and II cells detected with the CD95 ligand. Cell Death Differ 6, 821-2.

81. de la Taille A, Chen MW, Shabsigh A, Bagiella E, Kiss A, Buttyan R. (1999) Fas antigen/CD-95 upregulation and activation during castration-induced regression of the rat ventral prostate gland. Prostate 40, 89-96.

82. Diaz JI, Pow-Sang JM, Mora LB, Seigne JD, Cantor AB, Dalton WS. (2000) Cytometric analysis of Fas and Bcl-2 expression in normal prostatic epithelium and prostate cancer. Urol Oncol 2000: $5,149-154$.

83. Takayama H, Takakuwa T, Dong Z, Nonomura N, Okuyama A, Nagata S, Aozasa K. (2001) Fas gene mutations in prostatic intraepithelial neoplasia and concurrent carcinoma: analysis of laser capture microdissected specimens. Lab Invest 81, 283-8.

84. Costa-Pereira AP, Cotter TG. (1999) Camptothecin sensitizes androgen-independent prostate cancer cells to anti-Fas-induced apoptosis. Br J Cancer 80, 371-8.

85. Ng AY, Bales W, Veltri RW. (2000) Phenylbutyrate-induced apoptosis and differential expression of Bcl-2, Bax, p53 and Fas in human prostate cancer cell lines. Anal Quant Cytol Histol 22, 45-54.

86. Rokhlin OW, Bishop GA, Hostager BS, Waldschmidt TJ, Sidorenko SP, Pavloff N, Kiefer MC, Umansky SR, Glover RA, Cohen MB. (1997) Fas-mediated apoptosis in human prostatic carcinoma cell lines. Cancer Res 57, 1758-68.

87. Gewies A, Rokhlin OW, Cohen MB. (2000) Cytochrome c is involved in Fas-mediated apoptosis of prostatic carcinoma cell lines. Cancer Res 60, 2163-8.

88. Hedlund TE, Meech SJ, Srikanth S, Kraft AS, Miller GJ, Schaack JB, Duke RC. (1999) Adenovirus-mediated expression of Fas ligand induces apoptosis of human prostate cancer cells. Cell Death Differ 6, 175-82.

89. Hyer ML, Voelkel-Johnson C, Rubinchik S, Dong J, Norris JS. (2000) Intracellular Fas ligand expression causes Fas-mediated apoptosis in human prostate cancer cells resistant to monoclonal antibody-induced apoptosis. Mol Ther 2, 348-58. 